\title{
INTERPRETATIONS OF THE 'LIVING CONSTITUTION' IN THE AMERICAN LEGAL AND POLITICAL DISCOURSE. SELECTED PROBLEMS
}

DOI: 10.3935/zpfz.69.3.05

Pregledni znanstveni rad

Primljeno: ožujak 2019.

The synoptic character of the American Constitution has created favorable conditions for varied interpretations that were hotbeds of controversy and conflicts. The explanation of the U.S. Constitution is a problem of constitutional theory, constitutional doctrine, constitutional history, as well as political theory. The proponents of constitutional interpretation labeled as the living constitution are of the opinion that the Constitution should be treated as a legal act with a dynamic meaning depending on the time of interpretation. Originalism is perceived as the main alternative to the living constitution interpretation. Contemporary American scholars emphasize that there is no dichotomy between the proponents of living constitutionalism and the supporters of originalism.

Key words: amendment, constitution, interpretation, law, originalism

\section{INTRODUCTION}

Undeniably, the American political system was deeply thought through and projected by people who were well oriented in contemporary political conditions. The intention of some was to create new structures functioning in a republican manner. The American polity should have been based on active and broad partic-

Edyta Sokalska, Ph. D., Assistant Professor, Law and Administration Faculty, Warmia and Mazury University, Al. Warszawska 98, 10-702 Olsztyn, Poland; edyta.sokalska@ uwm.edu.pl;

ORCID ID: orcid.org/0000-0003-0903-7726 
ipation of citizens, and the construction of the American form of government was an intellectual experiment. The debate over whether the authors of the American Constitution intended to design a democratic government has been lively up to the present time in the American academic discourse. ${ }^{1}$ The answer appears to be complex. Some scholars take the view that the Framers did not intend to create a democracy in which the people rule directly. ${ }^{2}$ The size of the country and the distances between its inhabitants would have made that physically impossible. The Framers rather worried that a government in which all citizens directly participated "would be a government excessively subject to temporary popular passions and one in which minority rights would be insecure". ${ }^{3}$ It seems that their intent was to create a republic because they understood that it was a kind of government in which a system of representation was able to operate. By designing such a system, the Framers chose the possibility of the members of the House of Representatives to be elected directly by the American citizens. Finally, popular election to that chamber was approved but not unanimously, and the popular rule was not the only element of the new government. It was the state legislatures, and not the people, who would choose the senators. It was the electors, and not the people, who would choose the president. James Q. Wilson and John J. DiIulio, Jr., argue that "without these arrangements, there would have been no Constitution at all, for the small states adamantly opposed any proposal that would have given undue power to the large ones". ${ }^{4}$ Therefore, a direct popular election of the president would have made the populous states the dominant ones. The Framers "wished to observe the principle of majority rule, but they felt that, on the most important questions, two kinds of majorities were essential - a majority of voters and a majority of states". ${ }^{5}$

1 Burnham, W., Introduction to the Law and Legal Systems, $3^{\text {rd }}$ edn., West Group Publishing, St. Paul, 2002, pp. 3-4. See also the discussion on ratification in Ketcham, R. (ed.), The Anti-Federalist Papers and the Constitutional Convention Debates. The Clashes and Compromises that Gave Birth to our Form of Government. Edited and with an introduction by Ralph Ketcham, A Signet Classic, New York, 2003, pp. 12-14.

2 E.g., James Q. Wilson and John J. Dilulio, Jr. share this opinion, cf. Wilson, J. Q.; Dilulio, J. J., Jr., American Government Institutions and Policies, $11^{\text {th }}$ edn., Houghton Mifflin Company, Boston-New York, 2008, p. 27.

3 Loc. cit.

4 Ibid., p. 28.

5 Loc. cit. It is also interesting to consider that in the beginning of the 20th century Charles A. Beard presented his highly discussed opinion that it was the economic interest that had played an important part in the development of the Constitution. From his point of view the members of the Convention in Philadelphia who drafted the Constitution would have taken advantage of the establishment of the new sys- 
Although the approaches to the process of creation of new political structures were diverse, the ideas of the Founding Fathers were verified empirically. The Founding Fathers chose a political system and government which were based on a written constitution. As customs are always manifestations of their epoch, the proposed solutions were reflections of contemporary needs and the political situation. The American Constitution structured and formed the federal American polity and government, and it also structured American politics. ${ }^{6}$

Reflection on the interpretation of the American Constitution is impressive, and it is the subject of such academic disciplines as legal theory, constitutionalism, legal history, as well as political theory. The modest scope of this article does not allow for an exhaustive treatment of the subject, therefore, the present work is of a contributory character. My focus is on the development of the living constitution theory and the current described as originalism within the American academic constitutional theory. Therefore, the actions and opinions of the Supreme Court will not be taken into account in an exhaustive way. ${ }^{7}$ In the beginning there will be presented some characteristics and the development of the trends mentioned above. The second part of the paper will be devoted to the matter of changes to the American Constitution via the process of amendments. The questions asked in the article concern the American (sometimes controversial) academic debate. Regarding the mentioned discourse, the following questions can be advanced: Did the Framers intend any fixed method of constitutional interpretation? Is there really a dichotomy between living constitutionalism and

tem. See Beard, Ch. A., An Economic Interpretation of Constitution of the United Sates, Macmillan, New York, 1921 (1913), pp. 73-151; for more, see Sokalska, E., Legal and Political Dimensions of American Federalism: Development and Interpretations, Wydawnictwo Uniwersytetu Warmińsko-Mazurskiego w Olsztynie, Olsztyn, 2018, p. 162. Beard's research concerning the economic interest view was challenged in the 1950s. See here Brown, R. E., Charles Beard and the Constitution: A Critical Analysis of “An Economic Interpretation of the Constitution", Princeton University Press, Princeton, 1956, pp. 1-219; McDonald, F., We the People, Chicago University Press, Chicago, 1958, pp. 1-436.

6 Professor Mark Tushnet, unlike some legal scholars who consider the Constitution a project for American democracy, sees the Constitution as a framework for political debate. Cf. Tushnet, M., Why the Constitution Matters, Yale University Press, New Haven, London, 2010, p. 1.

7 The reflection on the American interpretation of the Constitution and legal acts is, of course, more extensive than the living constitution and originalism, which are taken into consideration in the present article. The issues of textualism, strict constructionism, pragmatic interpretation, or structural interpretation are also addressed by many scholars. For further reading, see Mitchell, J. F., Textualism and the Fourteenth Amendment, Stanford Law Review, vol. 69, no. 5, 2017, p. 1237. 
originalism from the perspective of American legal and political scholars? Are Americans afraid of the amendment method of constitutional changes? Why do they mostly choose to develop their Constitution by way of new interpretations? How to change the Constitution in order to keep pace with the times?

\section{THE SIGNIFICANCE OF INTERPRETATION}

American citizens often express the notion that the U.S. Constitution is permanent and stable. They revere their Constitution but they feel a constant sense of uneasiness by growing signs of political dysfunction. Economic situations generate fears that the political system may not be able to respond effectively. It is significant that the American Constitution has given rise to a remarkable range of interpretations over the years. ${ }^{8}$ A great amount of eminent American scholars have dealt with this problem. ${ }^{9}$ Professor Mark Tushnet, in his book Why the Constitution Matters, assumes that the Constitution matters because it protects American fundamental rights. He is also of the opinion that the Constitution matters because it symbolizes American political culture's commitment to the very idea that Americans have fundamental rights. However, he does not say anything about what those fundamental rights are or how they are protected, but he does say that protecting fundamental rights is important to American citizens. ${ }^{10}$ In this context, Tushnet also emphasizes the meaning of the interpretation of the Constitution exercised by the Supreme Court, assuring that the Constitution protects the fundamental rights through its constitutional interpretation. He also indicates that the president is a crucial player in determining what view of fundamental rights the Supreme Court takes. ${ }^{11}$

8 Ackerman, B., The Living Constitution, Harvard Law Review, vol. 120, no. 7, 2007, pp. 1743-1744.

9 E.g., the issue of the scholarly debate on the Constitution is raised in Main, J. T. (ed.), Is the American Constitution Obsolete?, Carolina Academic Press, Durham, 2013, pp. 1-316. A group of distinguished contributors of the book includes: Akhil Reed Amar, Mark Tushnet, Paul Finkelman, Mark A. Graber, Larry A. Sabato, Sanford Levinson, Richard M. Pious, Stephen Macedo, and others. See also Barber, S. A.; Flaming, J., Constitutional Interpretation. The Basic Questions, Oxford University Press, Oxford, 2007, pp. 1-201.

10 Tushnet, op. cit. (fn. 6), p. 11. It should be taken into account that the early debate on the American Constitution was to some extent devoted to the understanding of liberty in the 18th century.

11 Ibid., pp. 2-5. 


\section{THE NOTION OF THE LIVING CONSTITUTION}

The proponents of constitutional interpretation labeled as the living constitution are of the opinion that the Constitution should be treated as a legal act with a dynamic meaning depending on the time of interpretation. Therefore, it has, to some degree, the properties of an animate being. Every society develops its political, social, and economic structures in order to achieve the desired level of progress. It is not a simple mechanism, but a living and evolving organism. Such an understanding led to the view that the interpretation of the Constitution should be parallel with the advancement of the society and civilized changes of the world. In other words, it should keep pace with the times. It can be noticed that constitutional interpretation described as the living constitution is more than a specific method of interpretation - it is a part of a constitutional view or doctrine. It is often associated with judicial pragmatism, and non-originalist theories of interpretation. Pragmatists perceive, as a matter of social necessity, the Constitution as evolving over time. The interpretation of the Constitution in accordance with its original meaning or original intent is unacceptable in the case of the changing standards of the contemporary world. The proponents of the living constitution also advance the thesis that the Founding Fathers' intent was to formulate the document in a flexible language using broad terms in order to generate dynamic interpretation achieving the desired level of progress. The development of constitutional interpretation is easier to achieve than the improvement of the Constitution via acts of amendment.

\section{ORIGINALISM AS A METHOD OF INTERPRETATION}

In American legal literature originalism is perceived as the main alternative to the living constitution interpretation. It is significant that originalism is, in some way, associated with legal conservatives. Opponents of the living constitutional theory are of the opinion the Constitution should be changed through the amendment process. They argue that because living constitutionalists advocate interpreting the Constitution in accordance with current views, the act and legal norms are more open to judicial manipulation; in particular, they criticize judicial activism. The Framers of the Constitution provided for the process of amending the provisions, therefore, it was not their intent to change the meaning of their original words. The originalists also believe that in many cases the interpretation of the Constitution is directed at a desired policy outcome, which means that democracy is threatened. 
Originalism in the American academic discourse is often associated with the research of Robert Bork ${ }^{12}$, despite the fact that the roots of originalism can be traced much earlier. ${ }^{13} \mathrm{He}$ identifies originalism as "a self-conscious theory of constitutional interpretation". ${ }^{14}$ In his article "Neutral Principles and Some First Amendment Problems", he advances the requirement of neutrality when arguing that "the Supreme Court's constitutional role appears to be justified only if the Court applies principles that are neutrally derived, defined and applied". ${ }^{15}$ Bork discusses the question of when authority is legitimate in the context of the era of the Warren Court, and observes that "the Supreme Court regularly insists - that its results, and most particularly its controversial results, do not spring from the mere will of the Justices in the majority but are supported, indeed compelled, by a proper understanding of the Constitution of the United States". ${ }^{16}$ Therefore, he assumes, "value choices are attributed to the Founding Fathers, not to the Court". ${ }^{17}$ Bork understands that such a message of the Court is inspired by its conviction that citizens demand such an answer. Such an opinion raises the following question: should the Constitution be read and understood in accordance with the citizens' needs? What about the protection of minorities? Is the Constitution perceived as binding law and a set of general principles or only a judicial philosophy depending on the political and social evaluation?

\section{DEVELOPMENT OF ORIGINALISM}

Professor Andrew Coan identifies two periods of originalism, namely the era of old originalism and the era of new originalism. The period from 1970-1996 is regarded

12 Bork, R., Neutral Principles and Some First Amendment Problems, Indiana Law Journal, vol. 47, no. 1, 1971, pp. 1-35. See also Goldford, D. J., The American Constitution and the Debate over Originalism, Cambridge University Press, Cambridge, 2005, pp. 1-301. About the origins of originalism, see Rakove, J. N., Original Meanings: Politics and Ideas in the Making the Constitution, Vintage Books, New York, 1997, pp. 339-365. See also Alfange, D., Marbury v. Madison and Original Understanding of Judicial Review: In Defense of Traditional Wisdom, Supreme Court Review, vol. 9, 1993, pp. 329-446.

13 For more see the Supreme Court decisions presented by Lino A. Graglia in Graglia, L. A., Originalism and the Constitution: Does Originalism Always Provide the Answer?, Harvard Journal of Law \& Public Policy, vol. 34, no. 1, 2010, pp. 73-88.

14 Coan, A., Living Constitutional Theory, Duke Law Journal Online, vol. 66, Jun. 2017, p. 101.

15 Bork, op. cit. (fn. 12), p. 35.

16 Ibid., p. 3.

17 Ibid., p. 4. 
as the era of old originalism marked by the work of Robert Bork and the conservative representatives of legal thought who accepted his ideas. During its two decades, the program of originalists appeared to be reactive. ${ }^{18}$ In Coan's opinion “its overarching goal was to provide a theoretical and rhetorical justification for rolling back the liberal judicial activism of the Warren and early Burger Courts. (...) it sought to weaken judicial remedies against racial and gender discrimination". ${ }^{9}$

Keith E. Whittington also distinguishes the old and new versions of originalism emphasizing their political and intellectual contexts. He is of the opinion that in the United States originalism as a method of constitutional interpretation has a long history. In fact, it has been advanced from the very first debates over constitutional meaning and it was an important component of the American constitutional thought. In the late 1960s the critics of the Warren Court often referred to original intent to show their disagreement with the rulings of the Court. ${ }^{20}$ Therefore, the old originalism developed only to serve as the grounds for criticism of the constitutional doctrine developed by the Supreme Court under Warren $^{21}$ and early Burger. In the opinion of originalists the central problem of constitutional theory was "how to prevent judges from acting as legislators and substituting their own substantive political preferences and values for those of the people and their elected representatives". ${ }^{22}$ It was needed some mechanism "to redirect judges from essentially subjective consideration of morality to objective consideration of legal meaning". ${ }^{23}$ Originalists advanced the idea that by rooting the judges in the firm ground of the text of the Constitution, and by restricting the power of judicial review, the constant threat of political influence on law would be minimized. In the originalists' view, the living constitution was best realized by the Supreme Court, which was unfortunately settled in a political process. ${ }^{24}$ The old originalists also put emphasis on the subjective in-

18 Whittington, K. E., The New Originalism, Georgetown Journal of Law and Public Policy, vol. 2, 2004, pp. 599-613.

19 Coan, op. cit. (fn. 14), p. 102.

20 Whittington, op. cit. (fn. 18), p. 599. It should be emphasized that the Warren Court is presented in the American literature as the highest point in judicial power that has receded ever since.

${ }_{21}$ The Supreme Court under Warren disregarded, in some way, some conventional reasoning patterns, see here historically significant decisions in the cases concerning racial segregation, e.g., Brown v. Board of Education of Topeka (347 U.S. 483 (1954)); Bolling v. Sharpe (374 U.S. 497 (1954)); Cooper v. Aaron (358 U.S. 1 (1958)).

22 Whittington, op.cit. (fn. 18), p. 602.

23 Loc. cit.

24 For further reading, see, e.g., Gillman, H., The Collapse of Constitutional Originalism and the Rise of the Notion of the "Living Constitution" in the Course of American State- 
tentions of the Founding Fathers; therefore, that fact became the central concern of critics of originalism. The defenders of the Warren Court's legacy presented the argument that the original intent of the Founding Fathers is too remote to be understood efficiently. The Founders had many conflicting intentions and they were white men making rules to govern an agrarian society dependent on slave labor; they were pragmatists who expected the subsequent generations to adapt the Constitution to the needs of a developing society. ${ }^{25}$

It is significant that among legal scholars there were some constitutional historians engaged in the discussion on originalism. Jack N. Rakove in Original Meanings: Politics and Ideas in the Making of the Constitution ${ }^{26}$ illustrates the complexity of the political environment from which the American Constitution emerged, and as a historian, in some way, he influenced academic legal theory and constitutional thought. ${ }^{27}$ It is significant that "the historical literature of civic republicanism not only provided substantive grist for constitutional theory; it also influences the debate over history's normative significance for constitutional law". ${ }^{28}$ On the other hand, the debates between American legal theorists and constitutionalists were also valuable for historians and political scientists, and they reshaped the historical and political understanding of the Constitution. A. Raymond Randolph advanced the thesis that originalism in theory is different from originalism in practice. To interpret the Constitution from a historical perspective (which is what originalism advocates) we have to interpret history. "How well you perform the task of the historian will determine how accurately you interpret the Constitution". ${ }^{29}$

Building, Studies in American Political Development, vol. 11, no. 2, 1997, pp. 191247; Graglia, L. A., Interpreting the Constitution: Posner on Bork, Stanford Law Review, vol. 44, no. 5, 1992, p. 1019.

25 Cf. Brest, P., The Misconceived Quest for Original Understanding, Boston University Law Review, vol. 60, 1980, pp. 215-225.

26 Rakove, op. cit. (fn. 12), pp. 1-464.

27 See also the works of Gordon Wood (e.g., Empire of Liberty: A History of the Early Republic, 1789-1815, Oxford University Press, New York-Oxford, 2010, pp. 778), or Bernard Bailyn (The Ideological Origins of the American Revolution, Belknap Press, Cambridge, 1967, pp. 335).

28 Coan, op. cit. (fn. 14), p. 106. It is significant that civic republicanism emphasizes the interconnection of the freedom of individuals and civic participation with the promotion of the common good. The crucial difference between civic republicanism and classical liberalism is the liberal definition of freedom.

29 Randolph, A. R., Originalism and History: 'The case of Boumediene v. Bush', Harvard Journal of Law \& Public Policy, vol. 34, no. 1, 2010, p. 98. The author presents the way historical interpretation can support or distort constitutional analysis in the Supreme Court's opinion in Boumedine v. Bush decided in 2008. 
By the late 1980s, Ronald Reagan changed the complexion of the Supreme Court. In 1986 William Rehnquist, who was perceived as a conservative, started his tenure as Chief Justice. The policy of New Federalism was promoted by some of the Rehnquist Court rulings and the development of the new originalism is associated with some of them. ${ }^{30}$ There are opinions that the new originalism has flourished since the early $1990 \mathrm{~s} \cdot{ }^{31}$ In the American society there evolved a forceful demand for a new approach to the process of making constitutional decisions, which would be able to reconcile the proponents of the early versions of originalism and to justify greater judicial activism. Therefore, Keith E. Whittington and Randy E. Barnett developed the so-called original public meaning, explaining that it follows on from the commitment to written constitutionalism, and showing the interpretation-construction distinctions. ${ }^{32}$ Keith E. Whittington is of the opinion that "originalism is too committed to the democratically enacted constitutional text and too oriented to preserving decisions made in the past. For those who like judges to have more flexibility to make decisions about what constitutional rules should govern today and in the future, originalism will always seem too confining. For them originalism will always seem too "conservative"”. ${ }^{3}$

\section{ORIGINALISM VS. LIVING CONSTITUTION?}

As far as an academic approach to the subject of the interpretation of the American Constitution is concerned, in the 21st century we are witnessing

30 It is significant that the Rehnquist Court emphasized the value of states in the federal arrangement. In a series of cases, the Court resumed the dual federalism arguments, and provided clear evidence that the era of judicial restraint was over in the matters concerning federalism and the relationships between federal and states' governments. In several cases, including New York v. United States (505 U.S. 144 (1992)), United States v. Lopez (514 U.S. 549 (1995)), or Seminole Tribe of Florida v. Florida (517 U.S. 44 (1996)), the part of the Supreme Court was more active by limiting the power of federal government and directing the interpretation of the commerce clause in favor of state rights. For further reading, see Sokalska, op cit. (fn. 5), pp. 330-336.

31 Whittington, op. cit. (fn. 18), p. 599. Andrew Coan argues that the era of new originalism lasts from 1997 to 2015, cf. Coan, op. cit. (fn. 14), p. 106. In fact, the current developed with the Rehnquist Court more or less.

32 Barnett, R. E., An Originalism for Nonoriginalists, Loyola Law Review, vol. 45, no. 4, 1999, pp. 611-654. See also idem, Interpretation and Construction, Harvard Journal of Law \& Public Policy, vol. 34, no. 1, 2010, pp. 65-72.

33 Whittington, K. E., Is Originalism too Conservative?, Harvard Journal of Law \& Public Policy, vol. 34, no. 1, 2010, p. 41. 
an evolution. Jack M. Balkin, who is perceived as a liberal theorist ${ }^{34}$, in his monograph Living Originalism puts forward the thesis that originalism and living constitution are consistent. ${ }^{35}$ The question if the Constitution is a living document that adapts to changing circumstances, or if it should be interpreted in accordance with its original meaning should not be asked because the views are rather compatible than opposed. The text of the Constitution serves as a framework and an essential plan for politics. Subsequent generations must "keep the plan going to ensure that it remains adequate to the needs and values"36 of the American society. Therefore, constitutional politics must fulfill this duty. Balkin emphasizes that the Constitution itself requires faith that the project is worth continuing; therefore, constitutional change is a product of "the debate and striving over how to continue the plan". ${ }^{37}$ Constitutional interpretation is, in fact, multidimensional. It involves some historical arguments, ethos, structural elements, precedent, and consequences. ${ }^{38}$ A continuous process of living constitutionalist construction shows that the original public meaning of the Constitution is capacious, and by providing the constitutional framework, judges through judicial review, elected officials, or even social movements fulfill the contemporary reception of the American Constitution, and, in some respect, legitimize constitutional decisions.

It is significant that some theorists like Reva Siegel, Larry Kramer, or Robert Post, focusing on historical origins and development of judicial review in American constitutional law, argue that with the development of American deliberative democracy the citizens themselves are entitled to take control of the enforcement of constitutional law and its interpretation..$^{39}$ Larry Kramer, while presenting the popular constitutionalist project, assumes that "the power of the Constitution will always be in the people". ${ }^{40}$ Barry Friedman confirms

34 Cf. Coan, op. cit. (fn. 14), p. 113.

35 Balkin, J. M., Living Originalism, Belknap Press, Cambridge, 2011, pp. 1-480. See also idem, Framework Originalism and the Living Constitution, Northwestern University Law Review, vol. 103, no. 2, 2009, pp. 549-614.

36 Balkin, Living..., op. cit. (fn. 35), p. 4.

37 Loc. cit.

38 Cf. ibid., pp. 3-4.

39 Kramer, L., The People Themselves. Popular Constitutionalism and Judicial Review, Oxford University Press, Oxford, New York, 2004, pp. 1-376. See also the opinion on Kramer's popular constitutionalism in Harding, S., Kramer's Popular Constitution: A Quick Normative Assessment, Chicago-Kent Law Review, vol. 81, no. 3, 2006, pp. 11171126.

40 Kramer, op. cit. (fn. 39), p. 173. 
the importance of popular constitution, and he also recognizes the significance of judicial review in keeping with the constitutional standards of the epoch. ${ }^{41}$ It should be also noted that Bruce Ackerman, in the monograph presented in 1993, redefined the civic commitment in the future constitutional perspective and underlined the importance of political leadership in the development of popular support for constitutional politics. ${ }^{42}$

Andrew Coan, while presenting the outcome of his research, questions the dichotomy between living constitutionalism and originalism. He emphasizes the fact that constitutional history evolves over time, and in fact plays a significant part in constitutional interpretation and adjudication, and that "the two evolutionary processes are intertwined in complex ways". ${ }^{43}$ Constitutional theory evolves "through a process of reciprocal action with its environment". ${ }^{44}$ Some scholars look for transcended principles, and some seek more pragmatic and contextual terms. In fact, the evolutionary process of the interpretation of a constitutional act is complex.

Charles L. Barzun assumes that theories of legal interpretation have taken a 'positive turn' in recent years. ${ }^{45}$ While some representatives of the legal thought have argued that the debate on how to interpret the Constitution should be resolved taking into account the social facts that determine what the American positive law requires, "most of the commentary on the positive turn has focused on the substantive claim that what the law requires as a matter of constitutional interpretation is a version of originalism" ${ }^{46}$ Less attention has been paid to the methodological aspects of interpretation. The most important question for the positive turn seems to be "whether generating its alleged methodological benefits requires choosing among rival positivists theories" 4 , although, the proponents of the positive turn answer quite ambiguously to this question.

${ }^{41}$ Friedman, B., The Will of the People. How Public Opinion Has Influenced the Supreme Court and Shaped the Meaning of the Constitution, Farrar Straus \& Giroux, New York, 2009, e.g., pp. 4-5.

42 Ackerman, B., We the People. Foundations, p. I, The Belknap Press of Harvard University Press, Cambridge, London, 1993. See also paragraph 13 Reclaiming the Constitution in idem, We the People. Transformations, p. II, The Belknap Press of Harvard University Press, Cambridge, London, 1998, pp. 383-422.

43 Coan, op. cit. (fn. 14), p. 99.

44 Ibid., p. 114.

45 Barzun, Ch. L., The Positive U-Turn, Stanford Law Review, vol. 69, no. 5, 2017, p. 1323.

46 Loc. cit.

47 Loc. cit. 
To sum up, it is significant that the American Constitution itself is silent as far as constitutional interpretation is concerned. Either there was no consensus on how to interpret the Constitution, or the Framers had never intended any fixed method of interpretation. Therefore, it cleared the way for a reexamination of the rules of the Constitution, and for its interpretation in the light of the moral, cultural, and political climate of the time of explanation. In the American constitutional tradition there can be identified the evolution of a few, sometimes contradictory, scholarly trends concerning the interpretation of the Constitution. However, in the last two decades we can observe the development of academic debate involving legal theorists, historians, specialists in constitutional law, as well as representatives of political science and practitioners who focus on a reconciliation of the varied ways of interpretation and enforcement of constitutional law.

\section{HOW TO IMPROVE THE CONSTITUTION?}

One of the crucial problems of the living constitutional theory and originalism was how to change the Constitution in order to keep pace with the times. The proponents of the living constitution were of the opinion that this should be achieved by the means of interpretation, while originalists assumed that the Constitution should be changed by amendments due to the development of American society.

Immediately after the Constitution was ratified, it started to be the object of the debate concerning the ways in which it was supposed to be improved. However, in the view of an average citizen, the Constitution was well respected and any changes were not desired. Scholars and politicians respecting this broad popular support did not suggest many wholesale changes. Professor Lawrence Sager in his monograph Justice in Plainclothes. A Theory of American Constitutional Practice presents the opinion that what makes a constitution interesting is what people do with it. American people take the Constitution seriously. It is generally believed that the Constitution is a set of traditions and institutions. ${ }^{48}$ In the opinion of Akhil Reed Amar the U.S. Constitution was "not merely a text but a deed - a constituting" ${ }^{4}$

48 Sager, L. G., Justice in Plainclothes. A Theory of American Constitutional Practice, Yale University Press, New Haven, London, 2004, p. 1.

49 Amar, A. R., America's Constitution. A Biography, Random House Trade Paperbacks, New York, 2005, p. 5. 
The issue of the scope of constitutional amendments was the subject of the political and legal discourse almost immediately after the Constitution was proclaimed. It is significant that the problem of amendments of the Constitution has been a multifaceted phenomenon. There are two main approaches to the changes of the constitution in the American constitutional doctrine: formal amendments and informal amendments. Formal amendments are official changes, while informal amendments are substantive changes..$^{50}$ The mechanism of the formal amendments to the Constitution is complicated, multi-phase, and based on a wide political consensus. Therefore, the U.S. Constitution is rather placed among non-elastic constitutional acts which are hardly convertible. It is significant that thanks to some informal, substantive changes the Constitution is able to be up to the challenge of the present time. Informal changes may appear under the influence of some consequential political, social, economical, and other conditions, e.g. the development of new technologies, when the society, political elites, or federal or state bodies see the need for changes. ${ }^{51}$ In fact, the substantive changes develop by the means of dialogue and they are not codified. ${ }^{52}$ Thanks to the informal changes the American Constitution may adjust to the changeable political and social reality.

\section{THE IMPROVEMENT OF THE CONSTITUTION AND THE SEPARATION OF POWERS' ISSUE}

The 1980s were the decade when there were many suggestions concerning the improvement of the Constitution. A lot of suggested changes concerned the

50 Cf. Strauss, D., The Irrelevance of Constitutional Amendments, Harvard Law Review, vol. 114, 2001, pp. 1457-1505. For more, see the article of Richard Albert and cited there American literature, Albert, R., The Structure of Constitutional Amendment Rules, Wake Forest Law Review, vol. 49, 2014, pp. 913-975. The subject of amendments to the U.S. Constitution is vivid in Polish academic research, see, e.g., Lis-Staranowicz, D., Zmiana Konstytucji Stanów Zjednoczonych Ameryki (wybrane zagadnienia), Państwo i Prawo, vol. 12, 2018, pp. 73-87.

51 See the arguments for and against a non-elastic constitution in Jackson, V. C., The myth of (un)amendability of the US Constitution and the democratic component of constitutionalism, International Journal of Constitutional Law, vol. 3, 2015, pp. 575605. In the mentioned article Professor Vicki C. Jackson explores some claims about the amendment process of the U.S. Constitution.

52 See the examples of the informal, substantive changes of the U.S. Constitution in Lis-Staranowicz, D., Legitymizacja sądowej kontroli prawa w Stanach Zjednoczonych Ameryki, Wydawnictwo Uniwersytetu Warmińsko-Mazurskiego w Olsztynie, Olsztyn, 2012, p. 72. 
reorganization of the American federal system in opposite directions: either by strengthening federal governance, or by weakening it. The proponents of a strong government assume that one of the main difficulties with the Constitution is the separation of powers, and "by making every decision the uncertain outcome of the pulling and hauling between the president and the Congress, the Constitution precludes the emergence - except perhaps in times of crisis of the kind of effective national leadership the country needs". ${ }^{53}$ In this view, the American federal country faces a number of challenges that need decisive and fast actions which should be able to be formulated by the president and undertaken without any pressures from interest groups tied only to local or state interests. The critics of the separation of powers assume that the government agencies responsible for implementing federal programs are exposed to interference from legislators, so the president is in charge of the bureaucracy, but in reality, he must share his powers with the members of Congress and its committees. In other words, there is a fear that the separation of powers makes the president's powers too weak.

The proposals of a reduction of the separation of powers in the view of some authors include the following: to "allow the president to appoint members of Congress to serve in the cabinet (the Constitution forbids members of the Congress from holding any federal appointive office while in Congress); allow the president to dissolve Congress and call for a special election (election can now only be held on the schedule determined by the calendar); allow the Congress to require a president who has lost its confidence to face the country in a special election before his term would normally end".54 There are also some proposals to require the presidential and congressional candidates to run as a team in congressional districts, therefore a presidential candidate of a given district could be sure that "the congressional candidate of his party would also win in the district; have the president serve a single six-year term instead of being eligible for up to two four-year terms, this would presumably free the president to lead without having to worry about reelection; lengthen the terms of members of the House of Representatives from two to four years so that the entire House would stand for reelection at the same time as the president". ${ }^{55}$

In the 21st century there have been no amendments to the American Constitution despite the fact that amendment projects have been submitted more than once to the Congress. Professor Dorota Lis-Staranowicz argues that the

\footnotetext{
53 Wilson; Dilulio, op. cit. (fn. 3), p. 40.

54 Loc. cit.

55 Loc. cit.
} 
proposed changes would restrict the federal powers. ${ }^{56}$ However, some critics of the Constitution are in favor of a weaker federal government. They are of the opinion that sometimes the separation of powers may moderate the growth of federal government but sometimes the idea of democracy can produce unintended results by meeting demands of some interest claims rather than taking into account long-term values. Critics suggest various mechanisms, especially constitutional amendments that, for example, would reduce the amount of money collected in taxes by the federal government. There are also some proposals to curtail judicial power, but the opponents argue that if the Congress and the people do not approve of the way the Supreme Court has interpreted the Constitution, they can always amend this act to adopt some limitations on court powers.

\section{CONCLUSION}

The modern separation of powers mechanism which was implemented for the first time in practice in American constitutionalism tended to prevent the tyranny of the majority as represented by the people in the legislative body. The constitutional rule of law was incorporated into American constitutionalism in the form of judicial review of governmental acts by independent courts. A system of government was established with sufficient powers to realize the aims of the society taking into account the idea of individual rights, where the separation of powers mechanism was the attempt to support this challenge.

Undeniably, the synoptic character of the American Constitution created favorable conditions for varied interpretations that were hotbeds of controversy and conflicts. The American debate was not only on the interpretation of the Constitution, it also concerned the significance of judicial review. For some, judicial activism was treated as synonymous with living constitutionalism. The term was generally used to accuse judges of resolving cases based on their own political preferences and subjectivity. ${ }^{57}$

56 Lis-Staranowicz, op. cit. (fn. 50), p. 81. As Professors Jan Galster and Dorota Lis-Staranowicz argue, the debate concerning the scope of the amendments to the U.S. Constitution is revived from time to time. The case of the burning flag (Flag Burning Act of 1989) can serve as an example. For further reading, see Galster, J.; Lis-Staranowicz, D., Doktryna zastępowalności konstytucji. Ratione materiae wobec ratione temporis, Państwo i Prawo, vol. 10, 2016, pp. 27-28. See also the characteristics of the constitutional replacement doctrine developed in comparative law studies on constitutionalism, ibid, pp. 24-26.

57 The political character of the U.S. Supreme Court is noticed in Polish scientific literature (e.g., Małajny, R. M., Rola Sądu Najwyższego w procesie wykładni Konstytucji USA, 
Contemporary American scholars emphasize that dichotomy between the proponents of living constitutionalism and their adversaries - the supporters of originalism, is only apparent. From the perspective of the existence of the American federal state, 27 amendments to the American Constitution is a small number. Some of them, proposed and ratified in the 18th century in fact complemented the Constitution. It is obvious that Americans do not choose constitutional changes by means of amendments in a formal way. They prefer the development of the Constitution through new ways of interpretation and some informal - substantive changes. The informal changes to the American Constitution cause the American constitutional act to be still in touch with the changeable political reality. The question of how to read the Constitution is not answered exhaustively. I assume that judicial review is approved and confirmed in American legal culture, therefore the participants of the debate over the interpretation of the Constitution should take it into account while they question the objectivity of judges. Due to the fact that the Framers did not leave any obligatory method of interpretation, the text might be reexamined in the most efficient way. I am of the opinion that in the background of the American debate between the proponents of the living constitution theory and originalists (in its old and new versions) there have always been politics and political forces rather than any intellectual trends or philosophical grounds as some American legal and political scholars have emphasized in their research.

We may ponder over the extent to which the American discussions have influenced European constitutional-legal debates. In Europe - especially Central and Eastern Europe - the debates regarding historical interpretation and the interpretation of contemporary constitutions have been carried out. In post-Communist states they are often connected with the fact that the constitutional provisions were adopted at the beginning of transformation, and some part of the legal order consisted of regulations deriving even from real socialism. Therefore, constitutional courts in the 1990s widely applied the so-called

Gdańskie Studia Prawnicze, vol. 31, 2014, pp. 322-325), however, in the reception of Professor Łukasz Machaj, the American Supreme Court should not be identified with the primitive partyism, or only with the tool in the hands of a political party. Machaj quotes American scholars who share the same opinion (Lawerence Baum, David M. O’Brien, or William Lasser). Cf. Machaj, Ł., Pozycja ustrojowa Sadu Najwyższego Stanów Zjednoczonych, in Jabłoński, M. (ed.), Identyfikacja granic wolności i praw jednostki - prawnoporównawcza analiza tożsamego przypadku pod kątem praktyki stosowania prawa amerykańskiego i polskiego, seria e-Monografie, E-Wydawnictwo, Prawnicza i Ekonomiczna Biblioteka Cyfrowa, Wydział Prawa, Administracji i Ekonomii Uniwersytetu Wrocławskiego, Wrocław, 2016, pp. 36-37. See also here Bork, R., The Tempting of America: The Political Seduction of the Law, Free Press, New York, 1990, p. 16. 
dynamic understanding (taking into account contemporary expectations). In fact, the American concepts of originalism and living constitution influence the look at central-European (especially Polish) dispute regarding constitutional courts' activism from a broader perspective. ${ }^{58}$

\section{BIBLIOGRAPHY}

Ackerman, B., The Living Constitution, Harvard Law Review, vol. 120, no. 7, 2007, pp. 1737-1812.

Ackerman, B., We the People. Foundations, Part I, The Belknap Press of Harvard University Press, Cambridge, London, 1993.

Ackerman, B., We the People. Transformations, Part II, The Belknap Press of Harvard University Press, Cambridge, London, 1998.

Albert, R., The Structure of Constitutional Amendment Rules, Wake Forest Law Review, vol. 49, 2014, pp. 913-975.

Alfange, D., Marbury v. Madison and Original Understanding of Judicial Review: In Defense of Traditional Wisdom, Supreme Court Review, vol. 9, 1993, pp. 329446, https://doi.org/10.1086/scr.1993.3109583.

Amar, A. R., America's Constitution. A Biography, Random House Trade Paperbacks, New York, 2005.

Bailyn, B., The Ideological Origins of the American Revolution, Belknap Press, Cambridge, 1967.

Balkin, J. M., Framework Originalism and the Living Constitution, Northwestern University Law Review, vol. 103, no. 2, 2009, pp. 549-614.

Balkin, J. M., Living Originalism, Belknap Press, Cambridge, 2011, https://doi. org/10.4159/harvard.9780674063037.

Barber, S. A.; Flaming, J., Constitutional Interpretation. The Basic Questions, Oxford University Press, Oxford, 2007.

58 For more on the debates concerning constitutional courts' activism, see more in Maroń, G., Oryginalizm Antonina Scalli jako teoria wyktadni prawa, Przegląd Prawa Konstytcyjnego, vol. 4, 2010, pp. 46-52; Zubik, M.; Wiącek, M., Kompetencje sadu konstytucyjnego a granice swobody orzekania przez sędziów Trybunału Konstytucyjnego, Przegląd Sejmowy, vol. 4 (93), 2009, pp. 25-58; Morawski, L., Zasada trójpodziału wtadzy. Trybunat Konstytucyjny i aktywizm sędziowski, Przegląd Sejmowy, vol. 4 (93), 2009, pp. 59-74. About judicial activism see also Teitel, R., Transitional Justice and Judicial Activism - A Right to Accountability?, Cornell International Law Journal, vol. 48, 2015, pp. 385-422. 
Barnett, R. E., An Originalsim for Nonoriginalists, Loyola Law Review, vol. 45, no. 4, 1999, pp. 611-654.

Barnett, R. E., Interpretation and Construction, Harvard Journal of Law \& Public Policy, vol. 34, no. 1, 2010, pp. 65-72.

Barzun, Ch. L., The Positive U-Turn, Stanford Law Review, vol. 69, no. 5, 2017, pp. 1323-1388.

Beard, Ch. A., An Economic Interpretation of Constitution of the United Sates, Macmillan, New York, 1921 (1913).

Bork, R., Neutral Principles and Some First Amendment Problems, Indiana Law Journal, vol. 47, no. 1, 1971, pp. 1-35.

Bork, R., The Tempting of America: The Political Seduction of the Law, Free Press, New York, 1990.

Brest, P., The Misconceived Quest for Original Understanding, Boston University Law Review, vol. 60, 1980, pp. 204-238

Brown, R. E., Charles Beard and the Constitution: A Critical Analysis of "An Economic Interpretation of the Constitution”, Princeton University Press, Princeton, 1956.

Burnham, W., Introduction to the Law and Legal Systems, $3^{\text {rd }}$ edn., West Group Publishing, St. Paul, 2002.

Coan, A., Living Constitutional Theory, Duke Law Journal Online, vol. 66, 2017, pp. 99-115.

Friedman, B., The Will of the People. How Public Opinion Has Influenced the Supreme Court and Shaped the Meaning of the Constitution, Farrar Straus \& Giroux, New York, 2009.

Galster, J.; Lis-Staranowicz, D., Doktryna zastęowalności konstytucji. Ratione materiae wobec ratione temporis [The doctrine of the substitution of the constitution. Ratione materiae versus ratione temporis], Państwo i Prawo, vol. 10, 2016, pp. 23-40.

Gillman, H., The Collapse of Constitutional Originalism and the Rise of the Notion of the "Living Constitution" in the Course of American State-Building, Studies in American Political Development, vol. 11, no. 2, 1997, pp. 191-247, https://doi. org/10.1017/s0898588x00001656.

Goldford, D. J., The American Constitution and the Debate over Originalism, Cambridge University Press, Cambridge, 2005, https://doi.org/10.1017/ cbo9780511756214.

Graglia, L. A., Interpreting the Constitution: Posner on Bork, Stanford Law Review, vol. 44, no. 5, 1992, pp. 1019-150, https://doi.org/10.2307/1228934.

Graglia L. A., Originalism and the Constitution: Does Originalism Always Provide the Answer?, Harvard Journal of Law \& Public Policy, vol. 34, no. 1, 2010, pp. 73-88. 
Harding, S., Kramer's Popular Constitution: A Quick Normative Assessment, Chicago-Kent Law Review, vol. 81, no. 3, 2006, pp. 1117-1126.

Jabłoński, M., Identyfikacja granic wolności i praw jednostki - prawnoporównawcza analiza tożsamego przypadku pod kątem praktyki stosowania prawa amerykańskiego $i$ polskiego [The identification of the limits of the rights and liberties of an individual -legl and comparative analysis of the same example in the practice of the American and Polish law], seria e-Monografie, E-Wydawnictwo, Prawnicza i Ekonomiczna Biblioteka Cyfrowa, Wydział Prawa, Administracji i Ekonomii Uniwersytetu Wrocławskiego, Wrocław, 2016.

Ketcham, R. (ed.), The Anti-Federalist Papers and the Constitutional Convention Debates. The Clashes and Compromises that Gave Birth to our Form of Government. Edited and with an introduction by Ralph Ketcham, A Signet Classic, New York, 2003.

Kramer, L., The People Themselves. Popular Constitutionalism and Judicial Review, Oxford University Press, Oxford, New York, 2004.

Lis-Staranowicz, D., Legitymizacja sądowej kontroli prawa w Stanach Zjednoczonych Ameryki [The legitimization of the judicial review in the United States of America], Wydawnictwo Uniwersytetu Warmińsko-Mazurskiego w Olsztynie, Olsztyn, 2012.

Lis-Staranowicz, D., Zmiana Konstytucji Stanów Zjednoczonych Ameryki (wybrane zagadnienia) [The amendment to the Constitution of the United States - selected issues], Państwo i Prawo, vol. 12, 2018, pp. 73-87.

Machaj, Ł., Pozycja ustrojowa Sadu Najwyższego Stanów Zjednoczonych [The position of the U.S. Supreme Court in the American political system], in Jabłoński, M. (ed.), Identyfikacja granic wolności i praw jednostki - prawnoporównawcza analiza tożsamego przypadku pod katem praktyki stosowania prawa amerykańskiego i polskiego [The identification of the limits of the rights and liberties of an individual-legl and comparative analysis of the same example in the practice of the American and Polish law], seria e-Monografie, E-Wydawnictwo. Prawnicza i Ekonomiczna Biblioteka Cyfrowa. Wydział Prawa, Administracji i Ekonomii Uniwersytetu Wrocławskiego, Wrocław, 2016, pp. 35-50.

Main, J. T. (ed.), Is the American Constitution Obsolete?, Carolina Academic Press, Durham, 2013.

Małajny, R. M., Rola Sądu Najwyższego w procesie wyktadni Konstytucji USA [The part of the Supreme Cort in the interpretation of the U.S. Constitution], Gdańskie Studia Prawnicze, vol. 31, 2014, pp. 321-334.

Maroń, G., Oryginalizm Antonina Scalli jako teoria wyktadni prawa [The originalism of Antonio Scalia as a legal interpretation theory], Przegląd Prawa Konstytucyjnego, vol. 4, 2010, pp. 23-52. 
McDonald, F., We the People, Chicago University Press, Chicago, 1958.

Mitchell, J. F., Textualism and the Fourteenth Amendment, Stanford Law Review, vol. 69, no. 5, 2017, pp. 1237-1322.

Morawski, L., Zasada trójpodziału władzy. Trybunat Konstytucyjny i aktywizm sędziowski [Tripartiate separation of powers. The Constitutional Tribunal and judicial activism], Przegląd Sejmowy, vol. 4 (93), 2009, pp. 59-74.

Rakove, J. N., Original Meanings: Politics and Ideas in the Making the Constitution, Vintage Books, New York, 1997.

Randolph, A. R., Originalism and History: The case of Boumediene v. Bush, Harvard Journal of Law \& Public Policy, vol. 34, no. 1, 2010, pp. 89-98.

Sager, L. G., Justice in Plainclothes. A Theory of American Constitutional Practice, Yale University Press, New Heaven, London, 2004.

Sokalska, E., Legal and Political Dimensions of American Federalism: Development and Interpretations, Wydawnictwo Uniwersytetu Warmińsko-Mazurskiego w Olsztynie, Olsztyn, 2018.

Strauss, D., The Irrelevance of Constitutional Amendments, Harvard Law Review, vol. 114, 2001, pp. 1457-1505, https://doi.org/10.2307/1342685.

Teitel, R., Transitional Justice and Judicial Activism - A Right to Accountability?, Cornell International Law Journal, vol. 48, 2015, pp. 385-422.

Tushnet, M., Why the Constitution Matters, Yale University Press, New Haven, London, 2010.

Whittington, K. E., Is Originalism too Conservative?, Harvard Journal of Law \& Public Policy, vol. 34, no. 1, 2010, pp. 29-41.

Whittington, K. E., The New Originalism, Georgetown Journal of Law and Public Policy, vol. 2, 2004, pp. 599-613.

Wilson, J. Q.; DiIulio, J. J., Jr., American Government Institutions and Policies, $11^{\text {th }}$ edn., Houghton Mifflin Company, Boston, New York, 2008.

Wood, G., Empire of Liberty: A History of the Early Republic, 1789-1815, Oxford University Press, New York, Oxford, 2010.

Zubik, M.; Wiącek, M., Kompetencje sądu konstytucyjnego a granice swobody orzekania przez sędziów Trybunatu Konstytucyjnego [The constitutional court's competence and the limits of the freedom of adjudication of the Constitutional Tribunal judges], Przegląd Sejmowy, vol. 4 (93), 2009, pp. 25-58. 


\title{
Sažetak
}

\author{
Doc. dr. sc. Edyta Sokalska *
}

\section{INTERPRETACIJE “ŽIVOG USTAVA” U AMERIČKOM PRAVNOM I POLITIČKOM DISKURSU. ODABRANA PITANJA}

$U$ američkoj znanstvenoj literaturi do današnjih se dana vodi živa rasprava o tome jesu li autori američkog Ustava svjesno namjeravali kreirati oblik demokratske vlasti ili nisu. Odgovor se, naime, čini vrlo kompleksnim. Iako su pristupi stvaranju novih političkih struktura bili različiti, ideje utemeljitelja Ustava potvrđene su u praksi. Oni su pritom izabrali politički sustav $i$ sustav vlasti temeljen na pisanom ustavu. Rješenja sadržana u njemu odraz su onodobnih potreba i političke situacije, a njime su određeni daljnji razvoj i struktura američke federalne zajednice $i$ vlasti kao i američke politike.

Tumačenje Ustava SAD-a problem je kojim se bave ustavna teorija, ustavna doktrina, ustavna povijest i politička teorija. Zagovornici metode ustavnog tumačenja nazvane "živi ustav" (living constitution) smatraju da Ustav treba shvatiti kao pravni akt $s$ dinamičkim značenjem koje ovisi o vremenu njegova tumačenja. Glavna alternativa toj metodi je "originalizam" (originalism), prema kojem bi se Ustav smjelo mijenjati samo amandmanima. Prema zastupnicima te metode, teorija “živog ustava”, prema kojoj Ustav treba tumačiti u skladu s potrebama vremena i trenutačnim stavovima, sam Ustav i njegove odredbe čini više podložnima sudskim manipulacijama. Oni posebno kritiziraju sudski aktivizam te smatraju da ne bismo trebali uzimati da pravo govori ono što bismo mi htjeli da kaže. Važno je pritom uočiti da suvremeni američki znanstvenici smatraju da ipak ne postoji tako značajna dihotomija između stavova zagovornika dviju metoda.

Problem sadržaja i dosega ustavnih amandmana predmet je političkih i pravnih rasprava praktički od trenutka kada je Ustav proglašen. Riječ je o višerazinskom pitanju o kojem se raspravlja u radu, no bitno je istaknuti da se danas ipak preferiraju izmjene Ustava novim oblicima tumačenja i drugim neformalnim načinima.

Ključne riječi: amandman, ustav, interpretacija, pravo, originalizam

Dr. sc. Edyta Sokalska, docentica, Fakultet prava i javne uprave, Warmia and Mazury University, Al. Warszawska 98, 10-702 Olsztyn, Poljska; edyta. sokalska@uwm.edu.pl;

ORCID ID: orcid.org/0000-0003-0903-7726 
